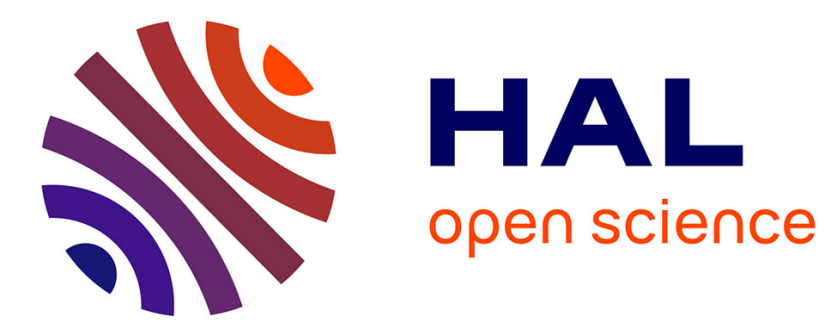

\title{
Feeding infants and young children. From guidelines to practice
}

\author{
Marion M. Hetherington, Joanne E. Cecil, Diane M. Jackson, Camille \\ Schwartz
}

\section{- To cite this version:}

Marion M. Hetherington, Joanne E. Cecil, Diane M. Jackson, Camille Schwartz. Feeding infants and young children. From guidelines to practice. Appetite, 2011, 57 (3), pp.791-795. 10.1016/j.appet.2011.07.005 . hal-01181309

\section{HAL Id: hal-01181309 \\ https://hal.science/hal-01181309}

Submitted on 29 Jul 2015

HAL is a multi-disciplinary open access archive for the deposit and dissemination of scientific research documents, whether they are published or not. The documents may come from teaching and research institutions in France or abroad, or from public or private research centers.
L'archive ouverte pluridisciplinaire HAL, est destinée au dépôt et à la diffusion de documents scientifiques de niveau recherche, publiés ou non, émanant des établissements d'enseignement et de recherche français ou étrangers, des laboratoires publics ou privés. 
Research report

\title{
Feeding infants and young children. From guidelines to practice ${ }^{\text {is }}$
}

\author{
Marion M. Hetherington ${ }^{\mathrm{a}, *}$, Joanne E. Cecil ${ }^{\mathrm{b}}$, Diane M. Jackson ${ }^{\mathrm{c}}$, Camille Schwartz ${ }^{\mathrm{a}}$ \\ ${ }^{a}$ Institute of Psychological Sciences, University of Leeds, LS2 9JT, UK \\ ${ }^{\mathrm{b}}$ School of Medicine, University of St Andrews, St Andrews Fife, Scotland, UK \\ ${ }^{\mathrm{c}}$ Rowett Institute of Nutrition and Health, University of Aberdeen, Aberdeen, Scotland, UK
}

A R T I C L E I N F O

\section{Article history:}

Received 8 July 2011

Accepted 8 July 2011

Available online 18 July 2011

\section{Keywords:}

Infant feeding

Healthy eating

Learning

Food preferences

Eating habits

\begin{abstract}
A B S T R A C T
Following a workshop on infant feeding held at the Rowett Institute of Nutrition and Health, University of Aberdeen on March 17, 2010 experts were invited to exchange ideas and to review evidence on both pre and post natal dietary environments in shaping children's eating habits. A central theme during the workshop was the idea of "sensitive periods" during infancy for learning about foods and a particular focus was developed around acceptance and intake of fruits and vegetables. Presentations covered the guidelines provided by various governments on how to feed infants during weaning; the importance of the in utero experience; the impact of varying the sensory experience at weaning; the effect of parenting styles and practices on children's eating habits; the use of visual experience in promoting intake of vegetables; and reports from mothers regarding their decisions about weaning and the introduction of vegetables. This collection of papers seeks to review guidance from governments on feeding infants and to consider current evidence on parental feeding practices with the aim of enhancing insight into best practice in establishing healthy eating in children.
\end{abstract}

() 2011 Elsevier Ltd. All rights reserved.
The first years of life are a critical period in the development of a child; it is a period of rapid growth, with major changes in motor and cognitive function. This early period is punctuated by specific milestones in which infants acquire gross motor skills such as sitting without help to fine motor skills, including those related to feeding from reaching for foods to self-feeding (Carruth \& Skinner, 2002). The subject of infant feeding is emotive as it is complex. In contrast to the consensus that "breast is best", there has been much debate around the "what, when and how" of solid food introduction and how best to feed infants beyond the weaning period. Governments produce guidelines to facilitate infant feeding (Schwartz, Scholtens, Lalanne, Weenen, \& Nicklaus, 2011) but whether or not these are heeded appears variable (Caton, Ahern, \& Hetherington, 2011).

The experience which can shape this early period occurs before birth (Cooke \& Fildes, 2011). Gestation is a time when the developing foetus is exposed to components of the maternal diet and this is then followed by a milk feeding period which can complement and expand the infant's sensory experience through breastfeeding (Cooke \& Fildes, 2011). The period of weaning when complementary foods are introduced is a crucial

\footnotetext{
The workshop was funded by EU FP7 Marie Curie IAPP 230637 "VIVA: V is for Vegetable - Applying Learning theory to increase liking and intake of vegetables". The authors wish to thank the EU for its support of this project, all the experts who agreed to contribute to this event and to those who submitted papers for this issue. * Corresponding author.

E-mail address: m.hetherington@leeds.ac.uk (M.M. Hetherington).
}

time of transition from milk to culturally appropriate family foods. This period using specially prepared foods is unique to humans (Sellen, 2007); other mammals tend to experience suckling then independent foraging with little reliance on transitional feeding. Unlike other mammals, the human infant is persuaded, cajoled and rewarded for trying new foods and so uniquely parenting styles impact on this early feeding experience (Blissett, 2011). Parents can use a variety of ways to encourage children to eat well through taste and repeated exposure, but as infants become more neophobic they may accept or refuse to taste foods on the basis of visual recognition (Heath, Kennedy, \& Houston-Price, 2011). The journey made by the developing foetus to the self-feeding child is the focus of this Special Issue of Appetite. This period determines the pattern of acquiring eating habits throughout life (Nicklaus, Boggio, Chabanet, \& Issanchou, 2004, 2005) and is crucial for establishing the foundation of a healthy diet.

\section{A start before birth}

The Barker hypothesis has transformed the ways in which foetal origins and later health risks are understood (Barker, 1992). In much the same way, early infant nutrition is identified as crucial for both the immediate growth and well-being of the infant and for later "programming" of health status (Lucas, 2005). Early food experience has therefore been studied to identify critical stages in the acquisition of food habits (Cooke \& Fildes, 2011; Nicklaus, 2011). It has been proposed that these early stages in feeding will have long lasting and profound effects on appetite 
regulation, food preferences and food intake. Even before birth, the developing foetus experiences the food environment through volatile compounds passed from the mother to the amniotic fluid (Schaal, Marlier, \& Soussignan, 1998, 2000; Mennella, Johnson, \& Beauchamp, 1995). Thus, although babies are adapted to accept breast milk which is the perfect fit for their needs and provides a complex taste environment, they have already had exposure to features of the maternal diet. Mothers who choose to breastfeed their babies continue to expose them to features of their diet (good and bad) and this link between the in utero and postnatal periods constitutes a form of chemosensory learning or chemical continuity (Schaal \& Orgeur, 1992).

\section{Breast is best}

Breastfeeding for at least 4 months confers many benefits to the developing infant (such as improved immunological function; Oddy et al., 2011), and to the mother (including lower retention of weight gain postpartum (Østbye, Krause, Swamy, \& Lovelady, 2010) compared to formula feeding. Breastfeeding has the potential to protect against obesity for the child (Arenz \& von Kries, 2009); and it may also encourage and enhance infants ability to express nutritional wisdom, or the self-regulation of energy intake (e.g. Heinig, Nommsen, Peerson, Lonnerdal, \& Dewey, 1993; Li, Fein, \& Grummer-Strawn, 2010). Breastfed babies are more willing to try and to accept novel foods than formula fed babies perhaps as a function of early exposure to such flavours via breast milk (Sullivan \& Birch, 1994). This phenomenon described as a "flavour bridge" may make later transitions in feeding smoother especially during weaning (Mennella \& Beauchamp, 2005; Mennella, Jagnow, \& Beauchamp, 2001). This kind of early flavour learning could even last until adulthood as illustrated by the impact of consuming a vanillin flavoured formula in infancy on the preference for a ketchup flavoured with vanillin in adults (Haller, Rummel, Henneberg, Pollmer, \& Köster, 1999).

The extent to which maternal dietary cues are transmitted seem to be variable across individuals and highly dependent on the type of compound (Hausner, Bredie, Mølgaard, Petersen, \& Møller, 2008). Due to variations in the composition of volatiles in mother's milk, breastfed infants are more familiar with novel flavours and changing flavours than formula fed infants partly explaining the facilitative effect of breastfeeding on food acceptance (Hausner, Nicklaus, Issanchou, Mølgaard, \& Møller, 2010). Breastfeeding encourages acceptance of novel foods as a result of exposure to specific flavour compounds. Given the sensory advantage of breastfeeding and the potential long lasting effects of some milk feeding experiences on later dietary outcomes, promoting a varied and healthy diet during pregnancy and lactation will benefit the baby. Early flavour learning through breastfeeding may confer an advantage to the infant by early exposure to healthy foods provided that the mother has a healthy diet (Forestell \& Mennella, 2007; also Cooke \& Fildes, 2011).

The World Health Organisation (WHO) has over the past decade advocated that infants should be breastfed exclusively for 6 months (WHO, 2001). The first of its guiding principles for the introduction of complementary feeding for breastfed infants states that one should "Start at six months of age with small amounts of food and increase the quantity as the child gets older, while maintaining frequent breastfeeding" (page 5, WHO, 2003). Exclusive breastfeeding for at least 4 months provides the best start in life, however the duration of exclusive breastfeeding which provides the greatest benefits against potential risks, has been the subject of debate specifically within the developed world (Fewtrell, Wilson, Booth, \& Lucas, 2010; Renfrew, McGuire, \& McCormick, 2011; Wright, 2011). There appears to be a mismatch between the advice to breastfeed exclusively for 6 months and the reality of less than $1 \%$ of mothers who manage this (Bolling, Grant, Hamlyn, \& Thornton, 2007); suggesting that the advice should be reappraised (Fewtrell et al., 2010).

The European Food Safety Authority (EFSA, 2009) states that for healthy term infants across the European Union the introduction of complementary foods between 4 and 6 months is safe and poses little risk either in the short term (risk of infection) or long term (development of allergies or obesity). An emerging literature supports this assertion by EFSA (see Fewtrell et al., 2010; for a full discussion). Whilst it is safe to introduce solid foods between 4 and 6 months there is convincing evidence that providing solid foods before 4 months can increase the risk of obesity in later life (Ong et al., 2006; Huh, Rifas-Shiman, Taveras, Oken, \& Gillman, 2011). The transition to solid foods is a crucial period for the child preparing the ground for a varied and omnivorous diet to optimise growth, but the advice on the process of weaning (what, how, when) varies between countries and cultures (Schwartz, Scholtens et al., 2011). Experts disagree about the optimal duration of exclusive breastfeeding and the lack of consensus across government agencies regarding weaning practices may serve to confuse parents. For example, UK mothers are guided by the needs of their infants rather than agency guidelines (Caton et al., 2011). Nevertheless, there appear to be optimal periods to introduce specific tastes, textures and forms of food in order to promote healthy eating.

\section{Sensitive periods}

It has been suggested that infants accept with more ease certain tastes and textures at specific times during early life (e.g. Harris, 1993) so called "sensitive periods" (Cashdan, 1994). These correspond to a time frame during which experience will impact strongly with long lasting effects, and may influence the development of later food preferences. These sensitive periods are not well described in the literature, but emerging evidence is beginning to shed light on these periods. For example, the timing and introduction of textured foods by 6 months affects later dietary choices and food fussiness (Coulthard, Harris, \& Emmett, 2009, 2010). Infants offered lumpy foods after 9 months consumed fewer fruits and vegetables and had more feeding problems at age 7 years than those offered these foods between 6 and 9 months (Coulthard et al., 2009). Also, babies appear to accept novel flavours early on in life, thus exposure to a protein hydrolysate formula (characterised by a relatively bitter taste) improves acceptance if offered before 3.5 months when there appears to be a "window" after which this taste is rejected (Mennella, Lukasewycz, Castor, \& Beauchamp, 2011). Notions of "sensitive periods" in the introduction of solid foods are discussed in more detail by Nicklaus (2011).

\section{Weaning and complementary feeding}

Weaning or complementary feeding (although not synonymous these two words are often used as if they were), constitutes the next major feeding transition. It corresponds to two particular changes: the cessation of lactation and suckling and the progressive introduction of foods other than milk in the infant diet (Humphrey, 2010). The WHO emphasizes that complementary feeding should be timely, safe, adequate in terms of variety of foods, frequency, amounts and consistency and complementary foods should be given in an appropriate way (Weaver \& Michaelsen, 2001). Interestingly from an evolutionary perspective, humans show a unique pattern: a prolonged period of post weaning dependency because infants lack sufficient motor and cognitive skills necessary to sustain themselves by locating and procuring an appropriate food supply to match their immature 
state. Infants depend on provision of such foods by carers (Humphrey, 2010).

The transition to family food is also charged with emotion since it marks an important social achievement i.e. readiness of the infant to join the family at mealtimes. Mothers are encouraged to enjoy this process, not to rush it and to respond to the needs of their babies. They are offered guidance on the "when, what and how" in infant feeding (Schwartz, Scholtens et al., 2011).

The optimal duration of exclusive breastfeeding and the timing of solid food introduction have been subject to debate (Fewtrell et al., 2010; Reilly \& Wells, 2005), with recommendations ranging from "not before 17 weeks and not later than 26 weeks" (Agostoni et al., 2008, p 99) to "after the age of 6 months, never before the age of 4 months" (WHO, 2001, 2003) (see Schwartz, Scholtens et al., 2011; for a review of selected international and national feeding guidelines). In practice, a review of 113 ethnographical and demographical reports from non-industrial societies back to 1873 showed that average age at introduction of non breast milk liquids was around 4.5 months, of solids was 5 months and the duration of breastfeeding was 29 months (Sellen, 2001). Prospective studies of the timing of solid food introduction in industrialised countries reveal the tendency for mothers to introduce solid foods before Government sanctioned guidelines. For example, despite receiving advice not to introduce solid foods to their babies before 4 months around $40 \%$ of a cohort of mothers from North East Scotland had already introduced solids by 12 weeks (Alder et al., 2004). Interviews with mothers had specifically identified characteristics of the baby as a determinant of the timing of solid food introduction, such as being a "big" or "hungry" baby (Anderson et al., 2001). According to Wright, Parkinson, \& Drewett, 2004 most babies are offered solid foods between 12 and 16 weeks, with only $6 \%$ receiving solids after 16 weeks. In this study, just over 600 mothers completed weaning diaries and the median age of solid food introduction was 14.6 weeks. The research by Wright et al. (2004) indicated that mothers were responding to avid infant appetites and the observation that bigger, faster growing boys were more likely to be weaned before 3 months appears to support the assertion that this is biologically driven by need; for example, boys tend to be bigger and therefore have greater energy requirements than girls. Caton et al. (2011) reported that mothers welcome the transition to solid foods as a means of "filling" their babies with a view to encouraging longer sleep duration. It is not clear if temperamental differences in infants are due to underlying or residual hunger, but mothers report that they believe infant distress is hunger related (Redsell et al., 2010) and feed them accordingly.

Recent studies suggest that there may be a shift in weaning practice closer to the recommendation. This is indicated by the UK Infant Feeding Survey (Bolling et al., 2007) in which a noticeable trend towards weaning at or after 4 months has been found. According to this survey $85 \%$ of mothers had introduced solid foods by four months in 2000 compared to just over half by 2005 . However, it is clear from studies in the US, Australia and UK that most mothers resist or reject the WHO guidance to wean around 6 months with the modal age closer to 4 months. In France, mothers tend to wean later, thus in 2005 on average mothers weaned at 5 months, but $13 \%$ of mothers had introduced solids before the age of 4 months (Turberg-Romain, Lelievre, \& Le Heuzey, 2007).

Beyond the crucial question of timing (when), the type of food offered (what) is also important. The impact of food chosen and in particular the role of sensory characteristics (i.e. taste, flavour, texture) is described in the review by Nicklaus (2011). Sensory properties of foods have the potential to shape later food acceptance. Interestingly, in the early stages of the weaning period (5-7 months) most foods are accepted by infants: the most bitter- or sour-tasting foods are not clearly rejected (Schwartz,
Chabanet, Lange, Issanchou, \& Nicklaus, 2011). Offering infants varied textures and forms prepared at home predicts greater intake of fruits and vegetables eaten at age 7 years compared with foods that are ready-made (Coulthard et al., 2010). Thus sensory properties of foods offered at weaning influence initial food acceptance and then influence later intake patterns.

Parents are offered guidance on when, what and how to wean. However, advice on the introduction of complimentary foods has changed over the past decade and there has been some confusion especially when advice is not consistent across varied sources (see Schwartz, Scholtens et al., 2011) and/or when maternal experience conflicts with Government guidelines (see Caton et al., 2011). Parents continue to shape children's food habits beyond the first year of life (Blissett, 2011) but explicit guidance to parents about feeding their child beyond this period tends to be more limited compared with guidance about weaning.

\section{Parental influences on feeding}

The parental role in shaping child feeding behaviour is central, influencing the intake of family foods and even the rate of weight gained in the first year of life (Farrow \& Blissett, 2006). Not only as drivers of when and what to eat, parents importantly transmit their influence on how a child is fed through specific interactions known as parenting styles and practices (Darling \& Steinberg, 1993). Specific styles and practices used by parents influence food acceptance through early childhood and beyond. Whereas the notion of parental 'style' tends to reflect a trait perspective, and has been referred to as the emotional climate of or type of parental attitude in interacting with children (Darling \& Steinberg, 1993; Ventura \& Birch, 2008), the term parenting 'practice' usually reflects a type of behavioural strategy or technique used to facilitate or limit child feeding, often depending on the context at a particular time and place (Ventura \& Birch, 2008). Inconsistencies in these concepts complicate the literature, however, there is substantial evidence to suggest that an authoritative parenting style (i.e. one that is characterized by high warmth, responsiveness and provision of rules) appears to be associated with a healthier feeding outcome in early childhood (Blissett, 2011; Ventura \& Birch, 2008) compared with parenting styles that are either authoritarian (low in warmth and responsiveness and highly demanding), indulgent/permissive (high in emotional warmth, low in demandingness) or neglectful (low in warmth, low in demandingness).

Parental practices generally include behaviours or strategies to control child feeding, for example pressure to eat, restriction, monitoring and even the use of rewards. Practices such as pressure to eat and restriction have been the focus of much attention in the literature (e.g. Birch \& Davidson, 2001; Fisher \& Birch, 1999; Galloway, Fiorito, Francis \& Birch, 2006; Paul, Bartok, Downs, Stifter, Ventura, \& Birch, 2009) and have been associated with a range of undesirable child eating and weight outcomes. For example, maternal control though pressure to eat is negatively associated with consumption of fruit and vegetables in young children (Fisher, Mitchell, Smiciklas-Wright, \& Birch, 2002; Gregory, Paxton, \& Brozovic, 2011; Wardle, Carnell, \& Cooke, 2005) and is associated with negative comments about those 'pressured' foods (Galloway et al., 2006). Maternal control through use of restrictive feeding practices serve to increase attention and preferences for those very foods that are 'restricted' and has generally been associated with poorer fruit and vegetable consumption in young children (Coulthard \& Blissett, 2009). However, restriction of high fat high sugar snack items has been associated with a better quality diet in families from materially deprived areas of Scotland suggesting a positive role of moderate restriction in the development of a healthy diet (Crombie et al., 2009). Overall, the environment provided by 
parents in the early stages of life set the foundation for the development of food habits in childhood.

\section{Feeding and the environment beyond infancy}

As children get older (toddler - pre-schoolers) they become more independent but parents remain a very important moderator of their feeding by modelling behaviour, feeding practices (Birch, 1999) and providing the family feeding environment. Food intake patterns of parents and young children have been shown to be related (Pérusse et al., 1988; Fisher et al., 2002) in part due to parents providing most of the foods that children of this age eat. The type of food provided is partly determined by cost and availability (Birch, 1999) but the way in which the family provide the food can influence the child feeding behaviour. Acceptance and intake of foods in children e.g. fruits and vegetables, can be increased by repeated exposure to these foods (Sullivan \& Birch, 1994) and recent research suggests that even just visual exposure to food pictures may increase the willingness to taste unfamiliar fruits (Heath et al., 2011).

The amounts and types of foods offered by parents influence a child's eating habits. For instance, food portion size has been shown to influence overall intake with higher portions leading to higher intakes (Fisher, Arreola, Birch, \& Rolls, 2007) and how the food is consumed within the family can have an effect such as the structure of the eating occasion. Eating in front of the TV, for example, has become commonplace and TV viewing has been linked with increased body fat in pre-schoolers (Jackson, Djafarian, Stewart, \& Speakman, 2009), increased preference for advertised foods (Borzekowski \& Robinson, 2001) and increased snack consumption (Campbell, Crawford, \& Ball, 2006). Children start to influence the family food environment themselves through "pester power" (Borzekowski \& Robinson, 2001) and they are themselves influenced outside of the family by their peers (Salvy, Elmo, Nitecki, Kluczynski, \& Roemmich, 2011), by exposure to advertising (Dovey, Taylor, Stow, Boyland, \& Halford, 2011; Halford, Boyland, Hughes, Oliviera, Dovey, 2007) and to what is happening at school (Anderson et al., 2005).

Although parents shape the family food environment, with age, children become more autonomous not only influenced by the food environment within the family but also being influenced by external factors outside the family. Thus, the early stage of life (birth to pre-school) is the main focus of this special issue and of the workshop which prompted these contributions.

\section{The VIVA workshop March 17, 2010}

Experts on infant feeding met at the Rowett Institute of Nutrition and Health, University of Aberdeen on March 17, 2010. The event was funded by the European Commission under a Marie Curie Industry Academia Exchange Program (EU FP 7 Marie Curie Industry-Academia Partnerships and Pathways (IAPP) 230637; RCN 90766). The aim of the workshop was to provide a forum in which to exchange knowledge and information on models of early feeding, weaning practice and on the introduction of vegetables to young children. During this workshop recent research and practice on early infant feeding were discussed. The proceedings of this event were generated by some of the speakers who agreed to contribute to this issue. The aim of this issue is to review recent evidence on the influences which shape infant feeding and food acceptance.

\section{References}

Agostoni, C., Decsi, T., Fewtrell, M., Goulet, O., Kolacek, S., Koletzko, B., et al. (2008). Complementary feeding. A commentary by the ESPGHAN committee on nutrition. Journal of Pediatric Gastroenterology and Nutrition, 46, 99-110.
Alder, E. M., Williams, F. L., Anderson, A. S., Forsyth, S., du Florey, C. V., \& van der Velde, P. (2004). What influences the timing of the introduction of solid food to infants? British Journal of Nutrition, 92, 527-531.

Anderson, A. S., Guthrie, C. A., Alder, E. M., Forsyth, S., Howie, P. W., \& Williams, F. L. (2001). Rattling the plate - reasons and rationales for early weaning. Health Education Research, 16, 471-479.

Anderson, A. S., Porteous, L. E., Foster, E., Higgins, C., Stead, M., Hetherington, M., et al. (2005). The impact of a school-based nutrition education intervention on dietary intake and cognitive and attitudinal variables relating to fruits and vegetables. Public Health Nutrition, 8(September (6)), 650-656.

Arenz, S. \& von Kries, R. (2009). Protective effect of breastfeeding against obesity in childhood Can a meta-analysis of observational studies help to validate the hypothesis? Advances in Experimental Medicine and Biology, 639, 145-152.

Barker, D. J. (1992). The fetal origins of adult hypertension. Journal of hypertension Supplemental, 10(December (7)), S39-S44.

Blissett, J. (2011). Relationships between parenting style, feeding style and feeding practices and fruit and vegetable consumption in early childhood. Appetite, 826-831.

Birch LL. (1999). Development of food preferences. Annals Reviews of Nutrition, 19, 41-62.

Birch, L. L., \& Davidson, K. K. (2001). Family environmental factors influencing the developing behavioral controls of food intake and childhood overweight. Pediatric Clinics of North America, 48, 893-907.

Bolling, K., Grant, C., Hamlyn, B., \& Thornton, A. (2007). Infant Feeding Survey 2005. The Information Centre.

Borzekowski, D. L., \& Robinson, T. N. (2001). The 30-second effect. An experiment revealing the impact of television commercials on food preferences of preschoolers. Journal of the American Dietetic Association, 101(1), 42-46.

Campbell, K. J., Crawford, D. A., \& Ball, K. (2006). Family food environment and dietary behaviors likely to promote fatness in 5- to 6-year-old children. International Journal of Obesity, 30(8), 1272-1280.

Carruth, B. R., \& Skinner, J. D. (2002). Feeding behaviors and other motor development in healthy children (2-24 months). Journal of the American College of Nutrition, 21, $88-96$.

Cashdan, E. (1994). A sensitive period for learning about food. Human Nature, 5, 279291.

Caton, S., Ahern, S. M., \& Hetherington, M. M. (2011). Vegetables by Stealth. An exploratory study investigating the introduction of vegetables in the weaning period. Appetite, 57, 816-825.

Cooke, L., \& Fildes, A. (2011). The impact of flavour exposure in utero and during milk feeding on food acceptance at weaning and beyond. Appetite, 57, 808-811.

Coulthard, H., \& Blissett, J. (2009). Fruit and vegetable consumption in children and their mothers Moderating effects of child sensory sensitivity. Appetite, 52(April (2)), 410-415.

Coulthard, H., Harris, G., \& Emmett, P. (2009). Delayed introduction of lumpy foods to children during the complementary feeding period affects child's food acceptance and feeding at 7 years of age. Maternal \&' Child Nutrition, 5, 75-85.

Coulthard, H., Harris, G., \& Emmett, P. (2010). Long-term consequences of early fruit and vegetable feeding practices in the United Kingdom. Public Health Nutrition, 13 2044-2051.

Crombie, I. K., Kiezebrink, K., Irvine, L., Wrieden, W. L., Swanson, V., Power, K., et al. (2009). What maternal factors influence the diet of 2-year-old children living in deprived areas? A cross-sectional survey. Public Health Nutrition, 12(8), 12541260 .

Darling, N., \& Steinberg, L. (1993). Parenting style as context. An integrative model. Psychological Bulletin, 113, 487-496.

Dovey, T. M., Taylor, L., Stow, R., Boyland, E. J., \& Halford, J. C. G. (2011). Responsiveness to healthy television (TV) food advertisements/commercials is only evident in children under the age of seven with low food neophobia. Appetite, 56, 440-446.

European Food Safety Authority. (2009). Scientific Opinion on the appropriate age for introduction of complementary feeding of infants. EFSA Journal, 7(12), 1423.

Farrow, C., \& Blissett, J. (2006). Does maternal control during feeding moderate early infant weight gain? Pediatrics, 118(August (2)), e293-e298.

Fewtrell, M., Wilson, D. C., Booth, I., \& Lucas, A. (2010). When to wean? How good is the evidence for six months' exclusive breastfeeding?. BMJ, 341, c5955.

Fisher, J. O., \& Birch, L. L. (1999). Restricting access to palatable foods affects children's behavioral response, food selection, and intake. American Journal of Clinical Nutrition, 69(June (6)), 1264-1272.

Fisher, J. O., Mitchell, D. C., Smiciklas-Wright, H., \& Birch, L. L. (2002). Parental influences on young girls' fruit and vegetable, micronutrient, and fat intakes. Journal of the American Dietetic Association, 102(January (1)), 58-64.

Fisher, J. O., Arreola, A., Birch, L. L., \& Rolls, B. J. (2007). Portion size effects on daily energy intake in low-income Hispanic and African American children and thei mothers. American Journal of Clinical Nutrition, 86(December (6)), 1709-1716.

Forestell, C. A., \& Mennella, J. A. (2007). Early Determinants of Fruit and Vegetable Acceptance. Pediatrics, 120, 1247-1254.

Galloway, A. T., Fiorito, L. M., Francis, L. A., \& Birch, L. L. (2006). 'Finish your soup'. Counterproductive effects of pressuring children to eat on intake and affect. Appetite, 46, 318-323.

Gregory, J. E., Paxton, S. J., \& Brozovic, A. M. (2011). Maternal feeding practices predict fruit and vegetable consumption in young children Results of a 12-month longitudinal study. Appetite, 29(April (57)), 167-172 1.

Haller, R., Rummel, C., Henneberg, S., Pollmer, U., \& Köster, E. P. (1999). The influence of early experience with vanillin on food preference later in life. Chemical Senses, 24, 465-467.

Halford, J. C., Boyland, E. J., Hughes, G., Oliveira, L. P., \& Dovey, T. M. (2007). ond-brand effect of television (TV) food advertisements/commercials on caloric intake and food choice of 5-7-year-old children. Appetite, 49(July (1)), 263-267. 
Harris, G. (1993). Introducing the infant's first solid food. British Food Journal, 95, 7-10. Hausner, H., Bredie, W. L. P., Mølgaard, C., Petersen, M. A., \& Møller, P. (2008). Differential transfer of dietary flavour compounds into human breast milk. Physiology \& Behavior, 95, 118-124.

Hausner, H., Nicklaus, S., Issanchou, S., Mølgaard, C., \& Møller, P. (2010). Breastfeeding facilitates acceptance of a novel dietary flavour compound. Clinical Nutrition, 29, 141-148.

Heath, P., Kennedy, O., \& Houston-Price, (2011). Increasing food familiarity without the tears. A role for visual exposure? Appetite, 57, 832-838.

Heinig, M. J., Nommsen, L. A., Peerson, J. M., Lonnerdal, B., \& Dewey, K. G. (1993). Intake and growth of breast-fed and formula-fed infants in relation to the timing of introduction of complementary foods. The DARLING study. Acta Paediatrica, 82, 999-1006.

Humphrey, L. T. (2010). Weaning behaviour in human evolution. Seminars in Cell \& Developmental Biology, 21, 453-461.

Huh, S. Y., Rifas-Shiman, S. L., Taveras, E. M., Oken, E. \& Gillman, M. W. (2011). Timing of Solid Food Introduction and Risk of Obesity in Preschool-Aged Children. Pediatrics, 127(3), e544-e551.

Jackson, D. M., Djafarian, K., Stewart, J., \& Speakman, J. R. (2009). Increased television viewing is associated with elevated body fatness but not with lower total energy expenditure in children. American Journal of Clinical Nutrition, 89, 1031-1036.

Li, R., Fein, S. B., \& Grummer-Strawn, L. M. (2010). Do infants fed from bottles lack selfregulation of milk intake compared with directly breastfed infants? Pediatrics, 125(June (6)), e1386-e1393.

Lucas, A. (2005). The developmental origins of adult health and well-being. Advances in Experimental Medicine and Biology, 569, 13-15.

Mennella, J. A., \& Beauchamp, G. K. (2005). Understanding the origin of flavor preferences. Chemical Senses, 30, I242-I243.

Mennella, J. A., Jagnow, C. P., \& Beauchamp, G. K. (2001). Prenatal and Postnatal Flavor Learning by Human Infants. Pediatrics, 107, e88-e90.

Mennella, J. A., Johnson, A., \& Beauchamp GK, (1995). Garlic ingestion by pregnant women alters the odor of amniotic fluid. Chemical Senses, 20, 207-209.

Mennella, J. A., Lukasewycz, L. D., Castor, S. M., \& Beauchamp, G. K. (2011). The timing and duration of a sensitive period in human flavor learning. A randomized trial. American Journal of Clinical Nutrition

Nicklaus, S. (2011). Children's acceptance of new foods at weaning. Role of practices of weaning and of food sensory properties. Appetite, 57, 812-815.

Nicklaus, S., Boggio, V., Chabanet, C., \& Issanchou, S. (2004). A prospective study of food preferences in childhood. Food Quality and Preference, 15, 805-818.

Nicklaus, S., Boggio, V., Chabanet, C., \& Issanchou, S. (2005). A prospective study of food variety seeking in childhood, adolescence and early adult life. Appetite, 44, 289297.

Oddy, W. H., Robinson, M., Kendall, G. E., Li, J., Zubrick, S. R., \& Stanley, F. J. (2011). Breastfeeding and early child development. A prospective cohort study. Acta Paediatrica, 100(July (7)), 992-999.

Ong, K. K., Emmett, P. M., Noble, S., Ness, A., Dunger, D. B., \& Team, A. S. (2006). Dietary energy intake at the age of 4 months predicts postnatal weight gain and childhood body mass index. Pediatrics, 117, e503-e508.

Østbye, T., Krause, K. M., Swamy, G. K., \& Lovelady, C. A. (2010). Effect of breastfeeding on weight retention from one pregnancy to the next. Results from the North Carolina WIC program. Preventive Medicine, 51(November (5)), 368-372.

Paul, I. M., Bartok, C. J., Downs, D. S., Stifter, C. A., Ventura, A. K., \& Birch, L. L. (2009). Opportunities for the primary prevention of obesity during infancy. Advances in Pediatrics, 56, 107-133.
Pérusse, L., Tremblay, A., Leblanc, C., Cloninger, C. R., Reich, T., Rice, J., et al. (1988). Familial resemblance in energy intake. Contribution of genetic and environmental factors. American Journal of Clinical Nutrition, 47(April (4)), 629-635.

Redsell, S. A., Atkinson, P., Nathan, D., Siriwardena, A. N., Swift, J. A., \& Glazebrook, C. (2010). Parents' beliefs about appropriate infant size, growth and feeding behaviour. Implications for the prevention of childhood obesity. BMC Public Health, 10 (November), 711.

Reilly, J. J., \& Wells, J. C. (2005). Duration of exclusive breast-feeding. Introduction of complementary feeding may be necessary before 6 months of age. British Journal of Nutrition, 94(December (6)), 869-872.

Renfrew, M. J., McGuire, W., \& McCormick, F. M. (2011). Analysis article on breast feeding was misleading. BMJ, 342.

Salvy, S. J., Elmo, A., Nitecki, L. A., Kluczynski, M. A., \& Roemmich, J. N. (2011). Influence of parents and friends on children's and adolescents' food intake and food selection. American Journal of Clinical Nutrition, 93(1), 87-92.

Schaal, B. \& Orgeur, P. (1992). Olfaction in utero. Can the rodent model be generalized? Quarterly Journal of Experimental Psychology B, Comparative and Physiological Psychology, 44(3-4), 245-278.

Schaal, B., Marlier, L., \& Soussignan, R. (2000). Human Foetuses Learn Odours from their Pregnant Mother's Diet. Chemical Senses, 25, 729-737.

Schaal, B., Marlier, L., \& Soussignan, R. (1998). Olfactory function in the human fetus. Evidence from selective neonatal responsiveness to the odor of amniotic fluid. Behavioral Neuroscience, 112(December (6)), 1438-1449.

Schwartz, C., Chabanet, C., Lange, C., Issanchou, S., \& Nicklaus, S. (2011a). The role of taste in food acceptance at the beginning of complementary feeding. Physiology $\mathcal{E}$ Behavior doi:10.1016/j.physbeh.2011.04.061.

Schwartz, C., Scholtens, P. A. M. J. , Lalanne, A., Weenen, H., \& Nicklaus, S. (2011b). Development of healthy eating habits early in life. Review of recent evidence and selected guidelines. Appetite, 57, 796-807.

Sellen, D. W. (2001). Comparison of infant feeding patterns reported for nonindustrial populations with current recommendations. Journal of Nutrition, 131, 2707-2715.

Sellen, D. W. (2007). Evolution of infant and young child feeding. Implications for contemporary public health. Annual Review of Nutrition, 27, 123-148.

Sullivan, S. A., \& Birch, L. L. (1994). Infant dietary experience and acceptance of solid foods. Pediatrics, 93(February (2)), 271-277.

Turberg-Romain, C., Lelievre, B., \& Le Heuzey, M.-F. (2007). Conduite alimentaire des nourrissons et jeunes enfants âgés de 1 à 36 mois en France. Evolution des habitudes des mères (Evolution of feeding behavior in mothers of infants and young children from 1 to 36 months old in France). Archives de Pédiatrie, 14, 1250-1258.

Ventura, A, \& Birch, L. (2008). Does parenting affect children's eating and weight status? International Journal of Behavioral Nutrition and Physical Activity, 5, 15.

Wardle, J., Carnell, S., \& Cooke, L. (2005). Parental control over feeding and children's fruit and vegetable intake. How are they related? Journal of the American Dietetic Association, 105(February (2)), 227-232.

Weaver, L. \& Michaelsen, K. F. (2001). A good start in life. Breast is best, but complementary foods should not be worse. Nutrition, 17(June (6)), 481-483.

WHO. (2001). Report of the expert consultation of the optimal duration of exclusive breastfeeding. p. 6

WHO. (2003). Complementary feeding. Report of the global consultation. Summary of guiding principles for complementary feeding of the breastfed child. p. 24

Wright, C. M. (2011). When to wean Infection more important than anaemia or allergy. BMJ 342(15) d1000.

Wright, C. M., Parkinson, K. N., \& Drewett, R. F. (2004). Why are babies weaned early? Data from a prospective population based cohort study. Archives of Disease in Childhood, 89, 813-816.
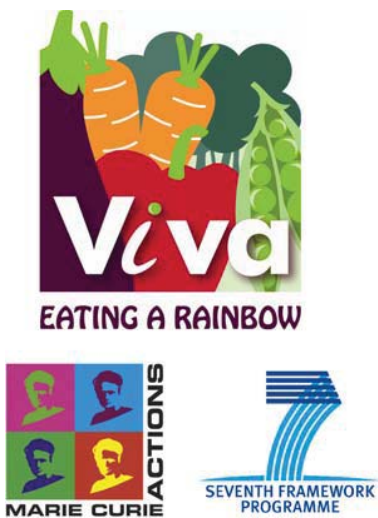